\title{
The importance of early diagnosis and management in total knee arthroplasty infection
}

\begin{abstract}
Periprosthetic joint infection (PJI) is a devastating complication after total joint arthroplasty and is often associated with poor clinical outcomes. Diagnosis can often be challenging and is based on conventional and molecular strategies. Treatment is complex and depending on many variables: timing of infection, bacteriology, implant stability, host condition, soft tissue impairment. Hence orthopaedic surgeons, microbiologists and infectious-disease physicians should work in a multidisciplinaryteam for an optimal treatment that includes different options: antibiotic-suppression, debridement, one- or two-stage prosthetic replacement and arthrodesis. The authors emphasize the importance of timely and accurate diagnosis and management to prevent long and costly procedures in case of false-positive diagnosis and to prevent recurrent implant failure in false-negative cases.
\end{abstract}

Volume 10 Issue 6 - 2018

\author{
Amendola L, Cauli V, Calabrò T, Comitini S, \\ Ortolani A,Tigani D \\ Department of Orthopedics and Traumatology, Spine Surgery, \\ Maggiore Hospital, Italy
}

Correspondence: Amendola L, Department of Orthopedics and Traumatology, Spine Surgery, Maggiore Hospital, ‘C. A. Pizzardi', Largo Nigrisoli I, 40100 Bologna, Italy, Email luca.amendola@yahoo.it

Received: February 24, 2018 | Published: December 27, 2018

Keywords: Total knee arthroplasty, infection, diagnosis, medical treatment, surgical treatment

\section{Pathogenesis and classification}

The infection of a knee prosthesis is a serious complication often characterized by a complex and prolonged diagnostic procedure and the treatment of which, even if could gain a healing of the septic process, not always results in a satisfactory functional result. ${ }^{1}$ Difficulties in the treatment of a knee prosthetic infection deal with the presence of the prosthesis which acts as a foreign body, feeding the persistence of the infection itself ${ }^{2}$. Microorganisms usually considered as nonpathogenic or poorly resistant to common antibiotic therapy could determine the clinical conditions in which the healing can be achieved only with the removal of the prosthetic implant ${ }^{3}$. There are particular situations at the base of the onset and persistence of so-called "foreign body" infections: the host organism reacts against biomaterials filling them with a thin film made of proteinaceous material. Some of these proteins have receptors specific for Staphylococcus Aureus and Epidermidis, determining contact that at least initially, is reversible. This condition can become irreversible through the production of a gelatinous substance (exopolysaccharides) by certain bacterial species as coagulase-negative staphylococci (St. Epidermidis, Capitis, Haemolyticus), Enterobacteriaceae, Pseudomonacee, Aciteobacter (Figure 1). Formation of a matrix glycoprotein then acts, defined by Gristina and Costeron, as "glycocalyx". ${ }^{2}$ The action of the glycocalyx is manifold: it forms a barrier against antibiotics and inhibits macrophage phagocytosis. ${ }^{3}$

Three forms of PJI can be classified according to the route of infection: perioperative (inoculation of microorganism during or immediately after surgery), contiguous (from an adjacent focus of infection) and hematogenous (microbial spread through blood from a distant focus of infection). Another classification is based on the onset time of symptoms after implantation: acute (less than 1 month) and chronic (more than 1 month). Acute infections are generally perioperative forms and caused by highly virulent organism (St. aureus, Gram-negative bacilli, anaerobic or polymicrobial infection); chronic infections are predominantly hematogenous or perioperative forms and caused by low-virulence organism. ${ }^{4}$

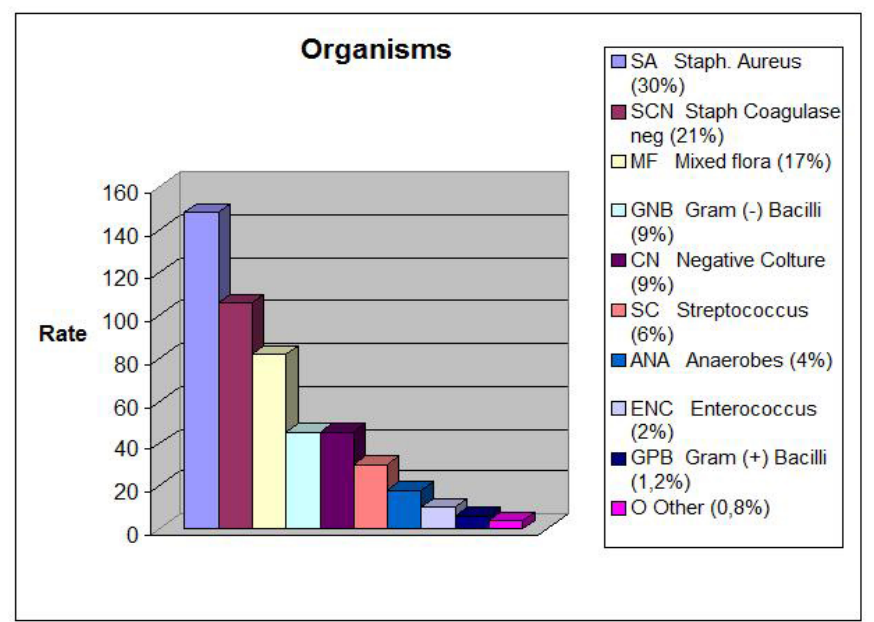

Figure I Rate of organisms involved in 494 infected TKA at the Mayo Clinic from 1969 to 1991.Almost $8 \%$ of cases have negative cultures.

\section{Risk factors}

Since knee prosthesis (-es) began to be used, the incidence of prosthetic infection after total knee arthroplasty (TKA) was $23 \%$ of cases. ${ }^{5}$ During Seventies, this percentage has been reduced by up to $5 \%,{ }^{6-9}$ while recent data reported by the Swedish register of knee replacements, certify a rate between $1 \%-2 \%$ of cases. ${ }^{10}$ The high incidence of infections reported in older series related to a period before the modern antibiotic prophylaxis, which has been proved to be the most important factor to limit the infection. The frequent use in those years of hinged prostheses has contributed to maintain the high rate of infections (incidence infection rate between $11 \%$ and $16 \%$ with these implants, even with appropriate prophylaxis). ${ }^{9,11}$ To explain the vulnerability of knee joint to infection in addition to the intrinsic characteristics as the shallowness of the joint and absence of adequate muscle coverage ${ }^{12}$ the literature reports various conditions related to the patient or surgery which are listed in Table $1 .^{6,13-15}$ 
Table I Risk factors for infection of the total knee arthroplasty.

\begin{tabular}{|c|c|}
\hline Patients-dependent factors & $\begin{array}{l}\text { Surgeons/operating room } \\
\text { dependent factors }\end{array}$ \\
\hline Immunologics deseases & Surgical environment \\
\hline - Reumatoid Arthritis & - Operating-room traffic \\
\hline - Diabetes mellitus & - Airflow \\
\hline - Neoplastic deseases & Surgical team \\
\hline Obesity & - Gloves \\
\hline Concomitant Infections & - Dressing \\
\hline - Urinary track & - Personalized protection suit \\
\hline - Skin & Intraoperative Surgical Factors \\
\hline - Dental & - Prophylactic antibiotics \\
\hline Previuosly infections & - Skin preparation \\
\hline - Septic arthritis & - Draping \\
\hline - Osteomyelitis & - Bleeding control \\
\hline Smoking & - Antibiotic cement \\
\hline Previous surgery & - Skin closure \\
\hline $\begin{array}{l}\text { Skin (psoriasis, eczema, ulcers) } \\
\text { Alcool abuse }\end{array}$ & $\begin{array}{l}\text { Prolonged operative time } \\
\text { (ie, }>2.5 \mathrm{~h} \text { ) }\end{array}$ \\
\hline $\begin{array}{l}\text { Malnutrition } \\
\text { (serum transferrin }<200 \mathrm{mg} / \mathrm{dL} \text {, } \\
\text { serum albumin }<3.5 \mathrm{~g} / \mathrm{dL} \text {, } \\
\text { total lymphocyte count } \\
<1500 \text { cells } / \mathrm{mm}^{3} \text { ) }\end{array}$ & \\
\hline \multicolumn{2}{|l|}{ AIDS/ HIV } \\
\hline Older patients (>75 yr) & \\
\hline
\end{tabular}

Infection risk is very high in patients with compromised immune system, as has been clearly demonstrated in rheumatoid arthritis, in which this complication is 2.6 times higher than in patients with osteoarthritis. ${ }^{14}$ Diabetes raises the incidence of infection up to $3 \%$ to $7 \%$ of cases. ${ }^{16}$ In the preparation and evaluation of a patient for a programmed intervention of arthroplasty, careful research of any infectious foci at the level of' odontostomatological apparatus, the genito-urinary tract, and respiratory system must be performed on all patients, in order to treat them immediately before surgery, as a source of infection by hematogenous bacteremia. Finally, is uncertain the incidence of infection in the presence of psoriatic lesions; Stern et al. ${ }^{17}$ reported an incidence of infection of $17 \%$ in patients with psoriasis, but has not been confirmed by subsequent studies.

\section{Diagnosis}

\section{Clinical evaluation}

The clinical scenario largely varies. In many acute infections, there is a sudden onset of one or more of the following symptoms: pain, which does not heal with rest and worsens with load-bearing, stiffness, local heat, swelling, and sometimes fever. This condition is often preceded by superficial necrosis and/or persistent discharge from the surgical scar as blood serum, serous and finally purulent. The presence of a sinus tract, finally, documents the subfascial extension of the infectious process. In contrast, chronic infections usually don't have many of acute signs and symptoms; they have an indolent course characterized by persistent joint pain with or without early implant failure (within 2-3 years after implantation), which makes it more difficult to distinguish from aseptic loosening. ${ }^{18}$

Recently, it has been demonstrated that prosthetic loosening within 2 years of implantation is highly predictive of infection. From a clinical point of view, mechanical aseptic loosening may present with pain with joint motion and weight bearing, whereas joint pain from a chronic infection may also occur at rest. ${ }^{4}$

\section{Imaging studies}

In the early period standard X-rays are usually negative, while the presence of signs of radiolucency, osteolysis, or migration of the prosthesis are common in case of mechanical loosening. ${ }^{4,6,12,18,19}$ Scintigraphy is indicated in cases of a valid suspicion of infection; ${ }^{4,20}$ scintigraphy with labeled leukocytes is able to assess the existence of an inflammatory focus and to localize it by means of $99 \mathrm{~m}$ Tc-labeled leukocytes that massively moves by chemotaxis and are found in large numbers in the inflammatory focus and, in doubtful cases, accuracy is enhanced by the use of radiocolloid. ${ }^{20}$

\section{Laboratory studies}

Laboratory testing for infection include nonspecific inflammatory markers that could be elevated in noninfectious diseases as well as in the early postoperative period. They include leukocytosis with significant increase in the percentage of neutrophils, increase in erythrocyte sedimentation rate (ESR) and C-reactive protein (CRP). In most cases, however, leukocytosis is uncommon and often not significant; ${ }^{5}$ also the ESR has a limited specificity in the study of a knee prosthesis sore. ${ }^{4,6,18,19}$ The CRP showed greater specificity as it tends to rise in the presence of infection while doesn't modified in the presence of a mechanical loosening of the prosthesis. ${ }^{6}$ In uncomplicated cases the CRP reaches maximum values at the 2 nd-3rd day post-operatively and tends to be normal after 3 weeks, while in the presence of an infection process were consistently higher (Figure 2). ${ }^{4,6,12,18}$ Hence it is considered the cheapest test to rule out infection.

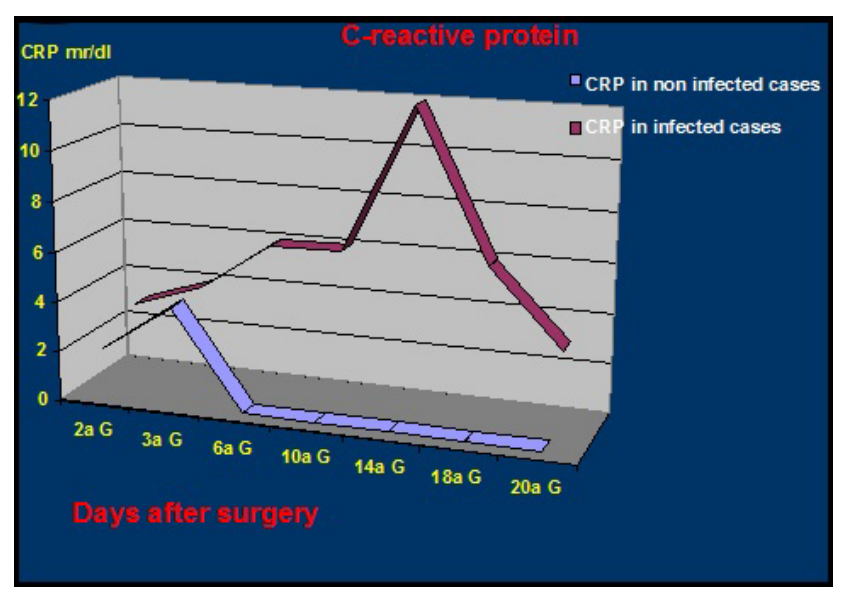

Figure 2 Comparison between CRP titer in infected and non-infected total knee arthroplasty (Courtesy of Prof. F. Ghisellini).

Recently, other biomarkers of inflammation including IL-6, TNFalfa, and procalcitonin has been investigated as biomarkers of PJI. Serum IL-6 reaches the peak 2 days after uncomplicated arthroplasty and rapidly returns to normal value. On the basis of a recent metaanalysis, it has the highest accuracy for the diagnosis, followed by the PCR? The ESR rate and the white blood cell count. About the TNF- 
alfa value there is a scarce of information in the literature and about procalcitonin, several studies demonstrated that a cutoff level of 0,35 $\mathrm{ng} / \mathrm{ml}$ revealed a sensitivity of $80 \%$ and specificity of $37 \%$.

\section{Microbiology}

The identification and study of bacterial sensitivity to antibiotics constitute an important element for prognosis and subsequent treatment. The collection of biological material to be sent to the laboratory should be aimed to the identification of aerobic and anaerobic bacteria, and fungi and mycobacteria in doubtful cases. Three different types of samples could be obtained preoperatively: blood cultures, fistula exudates and synovial fluid.

Blood cultures, despite are easily obtainable, have little use because have an extremely low sensitivity and specificity. Cultures from a fistula exudates are considered a useless tool because the most frequently isolated organism from these infections are common skin contaminant and can be isolated from the skin of the fistula, with scarce specificity. ${ }^{4}$

Aspiration of synovial fluid by fine needle aspiration has been questioned about the possibility of false negatives. ${ }^{6,18}$ Windsor and Insall ${ }^{19}$ consider this exam as fundamental for the diagnosis of infection in total knee arthroplasty. Duff et al reported data sensitivity, specificity and accuracy of $100 \%$ by needle aspiration before total knee revision surgery. ${ }^{21}$ In order to avoid false-negative fine-needle aspiration should be performed after discontinuation of antibiotic therapy at least 2-4 weeks before. If the aspirate fluid is negative but there remains a suspicion of infection, should be made at least two other attempts. ${ }^{21}$ In some cases where the diagnosis remains uncertain is recommended incision biopsy with multiple specimens from synovial and bone-prosthesis interface, ${ }^{6,22}$ because microorganism are embedded in biofilm and the synovial fluid could be sterile. In general, culture of fluid sample and soft tissue from around the implant for all revision arthroplasty is crucial (a minimum of 3 specimens should be sent to the laboratory), although in $7 \%$ to $11 \%$ of patients with prosthetic joint infection, cultures are negative. This can be explained with the capacity of microgranism to form a protective biofilm and to switch to a dormant metabolic form with small colony variants. Therefore a preoperative antibiotic treatment, reduces the sensitivity of microbiological culture of the tissue around the implant. ${ }^{23}$

\section{Role of alfa-defensin}

Unfortunately, there is no single test or finding that is $100 \%$ accurate for the diagnosis of PJI. About this, differents studies demonstrated the potenial clinical benefit of synovial fluid alfa-defensin levels. Defensins are a family of antimicrobial peptides that present a part of the innate immune system, whose role is to directly neutralize invading pathogens without the need of prior sensitization. Alfadefensins are primarily expressed in polymorphonuclear cells (PMNs) and nongranulocytes cells including natural killer cells. In PMNs they play a role in the oxygen -dependent killing of phagocytized pathogens and showed broad-spectrum antimicrobial activities against gram-positive and gram-negative bacteria. So they have been identified as markers of microbial activity in the innate inflammatory response and have shown potential promise in improving the accuracy preoperatory and intraoperatory diagnosis in PJI. In addition, alfa-defensins have been shown to outperform others biomarkers investigated as leukocyte esterase test strip, as well as diagnose PJI correctly $99 \%$ of the time when combined with synovial fluid C-reactive protein (CRP). Bingham et al performed a retrospective review of 57 patients undergoing PJI workup and demonstrated alfa-defensin to have a sensitivity and specificity of $100 \%$ and $95 \%$ respectively, demonstrating good diagnostic accuracy of this test for first-stage or single-stage revisions. Moreover if this immunoassay is not concordant with the presumptive diagnosis, serious consideration should be given to the possibility that the presumptive diagnosis is incorrect, triggering further clinical evaluation. Future research should focus on improved bacterial identification techniques and on specific clinical scenario (for example immediate postoperative patients or immunocompromised). ${ }^{24-26}$

\section{Sonification and molecular biology strategies}

As the differential diagnosis between asepting loosening and septic failure can be very diffiult, because clinical features are ambiguous and laboratory - imaging tests have notable rates of false positive and false results, further efforts are being made to improve our diagnostic capabilities. Sonication is a method based on the use of ultrasound that disloge biofilms from the surface of implants. The material obtained is subsequently placed in culture for a week. This tecnique can increase the sensitivity of microbiological studies from $54,4 \%$ to $60,8 \%$ for peri-prostethic tissue cultures and from $66,7 \%$ to $78,5 \%$ for fluid cultures. Puig-Verdie' et al. found in their study the significantly higher sensitivity of implant sonification compared with peri-implant tissue culture for the diagnosis of infection in delayed, but not early, failure. Thus, it can be a valuable aid in the differential diagnosis of aseptic loosening and septic faiure of the implant, even if the cultures also obtained by sonification have limited sensitivity in patients receiving antibiotics.

This can explained because early failure are usually caused by culture rapidly -growing micro-organisms that may not have had enough time to produce biofilm. The absence of biofilm explains the limited use of sonification and the higher sensitivity of tissue culture. Even if sonication has proved superior to conventional methods there still remain some clinically infected cases with negative cultures. For this, reason the use of sonification of the implants is not fully recommended in all guidelines. However, most authors think that the use of sonification cannot substitute the culture of periprosthetic tissues or any samples, but it should be performed whenever possible, because implant processing add valuable data that can help to the management or interpretation of all microbiologic results. When sonication cannot be performed because of a lack of technology, vortexing of implant has been demonstrated to be a viable alternative. Despite studies showing poorer results of vortexing than sonication for chronic infections or in patients with previous antibiotic therapy, the results are better than with conventonal cultures and very interesting.

Esteban et al. In their study have evaluated if an incubation time of two weeks decreased the number of negative cultures when compared with conventional seven day incubation. They found that the use of prolonged incubation times did not increase the detection of infection and when mycobacterial or fungal infection is suspected, special tissue cultures should be performed. However there are organism that are difficult to detect even if this approach is used. In these cases, the use of molecular biology including 16s rDNA amplification and sequencing is needful.

PCR (polymerase chain reaction) is a technology that enzymatically amplifies deoxyribonucleic acid (DNA) by means of sequence-specific oligodeoxynucleotide primers, to detect bacterial DNA. It is a rapid techique that provides definitive results in half day (compared with one week for culture). Many studies have shown high sensitivity but have been limited by the number of potential false-positive results. With the persistence of bacterial DNA after cell death, any bacterial contamination, even in an antibiotic -cleared infection, could cause a positive result in an otherwise sterile sample. To overcome this aspect, 
Bergin et al. in their study, explored the utility of mRNA (messenger ribonucleic acid) with use of reverse transcription - quantitative polymerase chain reaction (RT-qPCR) in place of DNA. They found that this strategy had higher specificity but lower sensitivity, due to the naturally low number of mRNA transcripts in the bacteria present in a clinical sample and high rate of degradation of mRNA after cell death. In front of this limited aspects, they evaluated the use of rRNA(ribosomia ribonucleic acid) hypothesizing that it would have higher sensitivity compared with mRNA because it make up more than $95 \%$ of the total RNA content. Moreover rRNA is a molecule more robust and is able to overcome more easily the extraction process. Interestingly, there is a delay of approximately one week during which rRNA detection persist although the samples remain culture -negative. Thus, a negative rRNA RT-qPCR assay may be used for assessing infections that have been partially treated with antibiotics (as the results of culture are notoriously poor for these patients) and in case of two-stage treatment to determine the appropriate timing of reimplantation. An other equally important aspect is that rRNA own highly conserved regions, so all bacterial pathogens can be rapidly identified with the universal primers. Similar highly conserved regions in mRNA are infrequent, making universal bacterial detection more difficult with mRNA in comparison with rRNA. In conclusion, molecular diagnostic methods compared with intraoperative tissue culture, especially if combined with sonication, have a higher sensitivity, a faster turnaround time and are not influenced by previous antimicrobial therapy, even if they still lack a system for detetion of antimicrobial susceptibility.

\section{Treatment options}

Treatment options for managing an infected TKA can be generally categorized as prosthetic retaining, prosthetic exchange and salvage procedure. Belong to first category suppressive antibiotic therapy and debridement with irrigation, which may be performed arthroscopically or through an open arthrotomy. The second category consists on prosthetic removal and subsequent reimplantation. According with the timing of the reimplantation, the exchange procedure is differentiated in early exchange (or one-stage procedure) and delayed or two-stage procedure. In case of one-stage technique the surgeon remove all the implants and cement, and thoroughly debride all infected tissues, excide all sinus tracts if presents, and install new implants using an organism-specific antibiotic cement during the same surgical procedure. The two stage exchange consists on the same meticulous debridement procedure followed by the implantation of an antibioticloaded spacer. The spacer acts as local antibiotic-delivery system to maintain limb length and the anatomical relationship of the joint. The second definitive reimplantation procedure is delayed of six to eight weeks; during this time intravenous or oral antibiotic therapy is administered based on recommendations of the infectious disease. A close clinical evaluation of the patients as well as the monitoring of hematological tests (ESR, C-reactive protein) complete most protocols for delayed reimplantation. The optimal outcome of treatment of an infection at the site of a total knee arthroplasty is restoration of a painless, well functioning joint and eradication of infection. In some cases, the infection is eradicated but it is not possible to retain good joint function, in which case arthrodesis or amputation may be the end result, which is considered as salvage procedure. , $^{6,10,12,18,23-33}$

The choice of the best treatment is based on several factors including the characteristics of the patient, the type of germ involved, the duration of symptoms and the condition of bone and soft tissues. Recently Tsukayama et al. ${ }^{34}$ have proposed a clinical classification with the aim to help the surgeon to make a choice of the appropriate management. According to this classification there are only two circumstances when surgery is not needed. The first one is a very superficial suture infection that usually can be treated with oral antibiotics. The second circumstance in which surgery may not be indicated is when the patient has a positive intraoperative culture. In this setting, a culture of an intraoperative specimen that is obtained during a revision arthroplasty for presumed aseptic loosening is subsequently found to be positive, usually for a coagulase-negative staphylococcus. The main consideration is whether the positive culture represents contamination or infection. To avoid this dilemma, it is recommend to obtain multiple specimens at the time of revision surgery, even for presumed aseptic etiologies, and making the diagnosis of infection only if the same pathogen is isolated from more than one specimen. The validity to obtain multiple specimens has been demonstrated by Atkins et al. ${ }^{22}$ who performed a prospective trial in 334 patients: they observed that at least three positive specimens are necessary to confirm diagnosis of infection. Treatment with antibiotics alone, without further operation, is curative in $90 \%$ of these situations.

In all other instances of deep infection, surgical intervention is indicated to adequately debride infected tissue. The most important decision to consider in this scenario is whether to remove the prosthesis. An attempt to salvage the involved prosthesis is reasonable when the infection presents acutely. There are two types of acute infections: early postoperative infections (EPOI) and acute hematogenous infections. ${ }^{11}$ By definition, an EPOI occurs within one month after implantation of the joint prosthesis. An acute hematogenous infection represents hematogenous seeding of the joint from another primary site of infection. Both types of acute infection present with local inflammation of acute onset and with systemic toxicity, and in these cases operative debridement is mandatory.

\section{Antibiotic suppressive therapy}

Antibiotic treatment is rarely used alone, as is unlikely to cure deep infection about knee prosthesis. $3,6,10,12,18,23,33-35$ However, in extremely sick and frail patients who may not tolerate surgical treatment, antibiotic alone may be used to control infection and prevent systemic progression. For this reason antibiotic management is defined as a suppressive treatment. The aim of the treatment is in fact those to arrest the grow up of the microorganisms. Antibiotic treatment alone should be considered in particular cases, as this treatment will not eliminate deep infection and is commonly associated with very poor results (Table 2).

Table 2 Summary of different studies showing poor results in the use of suppressive antibiotic treatment alone

\begin{tabular}{|c|c|c|}
\hline Author & $N^{\circ}$ of cases & $\mathbf{N}^{\circ}$ of success \\
\hline $\begin{array}{l}\text { Insall JN } \\
\text { Instr Course Lect } 1982\end{array}$ & 6 & 2 \\
\hline $\begin{array}{l}\text { Woods GW } \\
\text { Clin Orthop } 1983\end{array}$ & 7 & 4 \\
\hline $\begin{array}{l}\text { Grogan TJ } \\
\text { JBJS I } 986\end{array}$ & 3 & 1 \\
\hline $\begin{array}{l}\text { Johnson DP } \\
\text { JBJS } 1986\end{array}$ & 25 & 2 \\
\hline $\begin{array}{l}\text { Bengtson S } \\
\text { Acta Orthop Scand 199I }\end{array}$ & 225 & 44 \\
\hline $\begin{array}{l}\text { Wilson MG } \\
\text { JBJS } 1990\end{array}$ & 8 & 5 \\
\hline $\begin{array}{l}\text { Drancourt M } \\
\text { Antim Agents Chemoter } 1993\end{array}$ & 3 & 1 \\
\hline
\end{tabular}


A patient selected for antibiotic suppressive treatment must meet following criteria (Table 3):

a) The revision procedure is not feasible because important medical problems that contraindicate anesthesia and surgery.

b) The causative microorganism should have low virulence, and should be susceptible to an antibiotic that can be administrated orally.

c) It is imperative that the prosthesis should be not loose, and securely fixed to bone

d) The patient should be able to tolerate prolonged treatment without significant toxicity; therefore it must be periodically monitored indexes liver and kidney function, as well as the ESR and C- reactive protein to assess the effectiveness of antibiotic treatment. ${ }^{6,12,18}$

Table 3 Criteria used to decide to suppressive antibiotic treatment alone

\section{Indication for Antibiotic Suppressive therapy}

- General contraindications to surgery

- Low virulence of causative microrganism

- Susceptibility of the germ to oral anticiotics

- The antibiotic must be tolerated without problems and general toxicity

- The prosthesis must be stable

Prolonged antibiotic suppression therapy should be employed according the culture results, obtained by intra-articular fluid aspiration of sinus tract sample. In this contest the infection disease Consultant can make essential contribution to the development and supervision of safe, effective, and cost efficient treatment plans. The choice of a specific antibiotic is dictated by antimicrobial activity, pharmacokinetics, tissue penetration and as we have already said potential toxicities of the antimicrobials under consideration. In case of Staphylococcus infection, the use of more than one antibiotic, such as Rifampicin and Fluorchinolones has been shown to potentially improve treatment outcomes and should take into consideration. ${ }^{34}$

\section{Surgical debridement}

When infection is diagnosed within 4 weeks of its appearance, prosthesis is stable and the patient's general condition is good, articular debridement may represent a reasonable treatment option. ${ }^{36,37}$ The clinical conditions in which surgical debridement is indicated are early post-operative infection and hematogenous acute infection (Table 4). In both cases the onset is acute, with important local inflammation and often systemic toxicity. The long term results of debridement surgery are difficult to assess, as the literature data differ in relation to the type of germ involved, the duration and mode of administration of antibiotics and the evaluation criteria. The positive results after debridement vary greatly. ${ }^{36-39}$ The major series, however, show that the success rate is around $30 \%$ of cases $^{6,18,23,30}$ (Table 5).

Table 4 Indications for surgical debridement

Indications for surgical debridement
- Acute hematogenous infection or early post-operative infection
(within $4 / 6$ weeks).
- Absence of draining skin sinus.
- Stable prosthetic components.
- Staphylococcus Epidermis or Streptococcus.
- Staphylococcus Aureus (if surgery timing within 2 weeks).

Table 5 Surgical debridement

\begin{tabular}{|c|c|c|c|}
\hline Author & $\mathbf{N}^{\circ}$ of cases & $\begin{array}{l}\text { Success } \\
\text { cases (rate) }\end{array}$ & FU (months) \\
\hline $\begin{array}{l}\text { Woods GW } \\
\text { Clin Orthop } 1983\end{array}$ & 27 & $3(12 \%)$ & n.r. \\
\hline $\begin{array}{l}\text { Freeman MA } \\
\text { JBJS Br } 1985\end{array}$ & 6 & $5(83 \%)$ & $12-40$ \\
\hline $\begin{array}{l}\text { Johnson DP } \\
\text { JBJS } 1986\end{array}$ & 27 & $2(7 \%)$ & 33.6 \\
\hline $\begin{array}{l}\text { Grogan TJ* } \\
\text { JBJS I986 }\end{array}$ & 4 & $3(75 \%)$ & n.r. \\
\hline $\begin{array}{l}\text { Flood JN* } \\
\text { Arthroscopy } 1988\end{array}$ & 2 & $2(100 \%)$ & 30 \\
\hline $\begin{array}{l}\text { Borden LS } \\
\text { J Arthroplasty } 1990\end{array}$ & 11 & $5(45 \%)$ & 51 \\
\hline $\begin{array}{l}\text { Teeny SM } \\
\text { J Arthroplasty } 1990\end{array}$ & 21 & $6(29 \%)$ & 42.5 \\
\hline $\begin{array}{l}\text { Wilson MG } \\
\text { JBJS } 1990\end{array}$ & 31 & $17(55 \%)$ & 34 \\
\hline $\begin{array}{l}\text { Schoifet SD } \\
\text { JBJS 1990 } \\
\text { Bengston S }\end{array}$ & 31 & 7 (23\%) & 105.6 \\
\hline $\begin{array}{l}\text { Acta Orthop Scand } \\
|99|\end{array}$ & 154 & $37(24 \%)$ & 72 \\
\hline $\begin{array}{l}\text { Hartman MB } \\
\text { Clin Orthop |99| }\end{array}$ & 33 & $20(61 \%)$ & 54 \\
\hline $\begin{array}{l}\text { Burger RR } \\
\text { Clin Orthop 1991 }\end{array}$ & 39 & $7(18 \%)$ & 49.2 \\
\hline $\begin{array}{l}\text { Kramhoft M } \\
\text { J Arthroplasty I } 994\end{array}$ & 27 & $6(22 \%)$ & n.r. \\
\hline $\begin{array}{l}\text { Wasielewsky RC } \\
\text { J Arthroplasty1996 }\end{array}$ & 9 & $6(67 \%)$ & 57 \\
\hline $\begin{array}{l}\text { Wasielewsky RC* } \\
\text { J Arthroplasty I } 996\end{array}$ & I & $\mathrm{I}(100 \%)$ & 57 \\
\hline $\begin{array}{l}\text { Mont MA } \\
\text { J Arthroplasty } 1997\end{array}$ & 24 & $20(83 \%)$ & 48 \\
\hline $\begin{array}{l}\text { Segawa H } \\
\text { JBJS I999 }\end{array}$ & 10 prec & $5(50 \%)$ & 48 \\
\hline $\begin{array}{l}\text { Waldman BJ* } \\
\text { J Arthroplasty } 2000\end{array}$ & 16 & $6(38 \%)$ & 64 \\
\hline $\begin{array}{l}\text { Deirmengian C } \\
\text { J Arthroplasty } 2003\end{array}$ & 35 & II (35\%) & $24-120$ \\
\hline $\begin{array}{l}\text { llahi OA* } \\
\text { Arthroscopy } 2005\end{array}$ & 5 & $5(100 \%)$ & 41 \\
\hline
\end{tabular}

Literature review (*, patients with arthroscopic debridement; nr, not reported)

Some factors, however, have to be discussed. The early intervention for many authors is the most important factor for success. In a 1990 study Teeny et al. ${ }^{37}$ have observed that after 2 weeks of symptom onset the chances of success have drastically reduced. The importance of the concerning germ was demonstrated by Schoifet and Morrey in 1990, who reported the results of 31 cases of debridement in the presence of acute infection treated at the Mayo Clinic in Rochester. ${ }^{36}$ The healing of the infection was obtained only in 7 cases with a mean follow-up of 8.8 years. All patients in whom the infection was supported by Gram negative had a recurrence of the infection. The S.Aureus was involved in $29 \%$ of cases, while he had infected $58 \%$ of failures. More recently Deirmengian et al. ${ }^{4}$ reported 12 cases of failure out of 13 patients who had infection with S.Aureus, while healing was $56 \%$ of cases when the causative agent was the S.Epidermidis or Streptococcus. 
Debridement can be performed arthroscopically or through open arthrotomy. With the arthroscopic treatment have been reported positive results in selected patients treated within a few days after onset of symptoms. ${ }^{40}$ Arthroscopically, however, complete excision of synovial inflammation and/or infected tissue can be difficult in the presence of abundant scar tissue. ${ }^{41}$ Finally, it is impossible, with this method, to proceed to the replacement of the insert of polyethylene, which is however strongly recommended in these cases. ${ }^{6,18,23}$ The use of continuous washing with post-operative antibiotic solutions is controversial, ${ }^{42,43}$ but cannot find many supporters at the time. ${ }^{6}$ The debridement is not possible without adequate antibiotic treatment assessed in relation to the sensitivity of the infecting germ. The choice of the most effective drugs and the treatment duration is of relevance of infectious disease Consultant.

\section{Prosthetic replacement}

Reimplantation of a new prosthesis is obviously the desired preferred solution by the patients and the surgeons because it offers the possibility to re-establish the function of the knee. Even though eradication of infection should be considered as major goal of the treatment. Selection of patient for reimplantation correlates with several conditions, some are connected with the host whereas others are related to the characteristic of the infection and in particular with the virulence of the microorganism. Regarding the host condition, a patient with a deficient immune system or carrier of factors that diminished his/her metabolic, and/or hematopoietic capabilities should be considered a poor candidate for reimplatation. A useful staging prosthetic joint infections system designed to facilitate a comparison of outcomes in specific host cohorts has been proposed by Cierny and

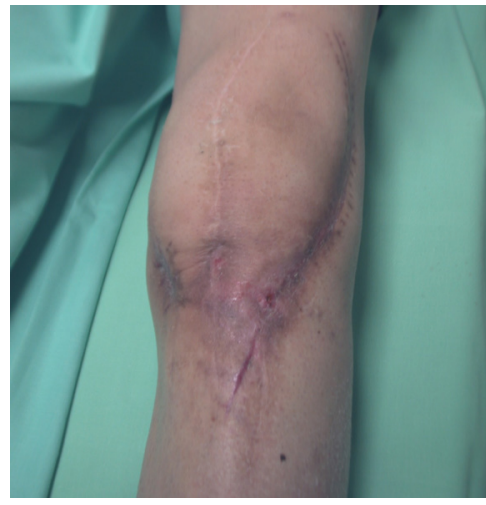

$\mathbf{a}$

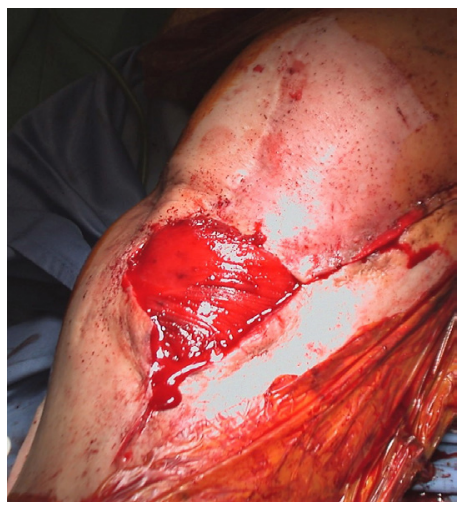

b

DiPasquale. ${ }^{44}$ According to this staging system the health condition of the patient is classified using parameters found previously which adversely affect wound healing. Systemic factors are malnutrition, immune deficiencies, chronic hypoxia, malignancies, diabetes mellitus, and extremes of age, chronic tobacco abuse and major organ failure. Local factors include chronic lymphedema, venous stasis, major vessel disease, arteritis, extensive scarring, radiation fibrosis, retained foreign bodies (suture, buckshot).

Others Authors noted a higher degree of failure in patients with rheumatoid arthritis compared with those with osteoarthritis or in case of diabetes mellitus. ${ }^{45}$ The increased predilection for infection is probably correlated with a greater tendency toward delayed or failed wound healing and diminished host resistance. ${ }^{46}$ This might be related to decreased neutrophils function ${ }^{47}$ and nutritional compromise. Regarding the nutritional status an albumin level of $<3.5 \mathrm{~g} / \mathrm{dL}$, a total lymphocyte count of $<1500$, or a serum transferrin level of $<262 \mathrm{mg} /$ $\mathrm{dL}$ have all been found to increase the risk of infection, length of hospital stay, and mortality in elderly patients. ${ }^{48,49}$

Another important factor that to take into account is grading of the local wound. An intact soft tissue envelope with normal perfusion is critical to eradicating the infection at the local site. An intact vasculature is necessary to deliver oxygen, immune cells, and mediators to the area of infection. If the local wound is damaged significantly, then undamaged fresh tissue can be used to fill deficits and reestablish a vital local status; local muscle rotational flaps could be helpful in some cases (Figure 3). If there is poor extremity perfusion, the real possibility of success are extremely reduced

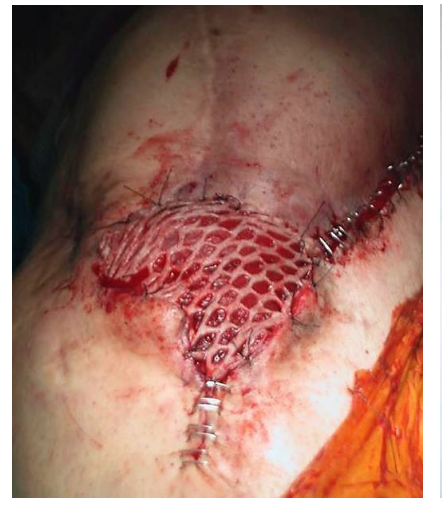

C

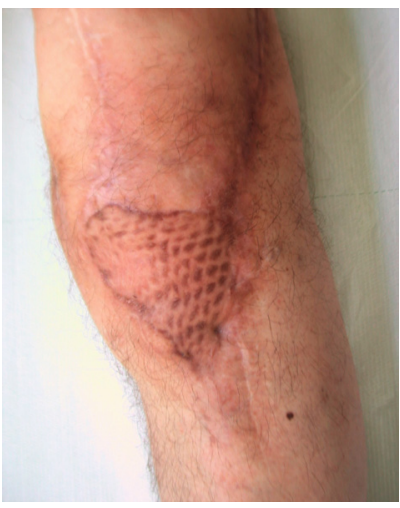

d

Figure 3 a) local wound aspect before antibiotic-loaded cement removal and reimplantation of a new prosthesis b) medial gastrocnemius flap coverage c) thiersch graft d) I year follow-up.

\section{Prosthesis removal}

The removal of prosthesis and surgical debridement is challenging and difficult. First at all is important to consider which surgical exposure to use before the operation. Isolated preexisting longitudinal approaches should be reused; in particular a well-healed medial parapatellar incision should always be used rather than making a new adjacent midline incision. In cases where more than one longitudinal incision are present is better to select the more lateral one (Figure 4), as blood supply entering from the medial side is significantly more than that entering from the lateral side. Revision incision should be long enough to provide wide exposure of distal femur and proximal tibia, and to allow extensive procedures if necessary. Intraarticular access could be in fact limited by a tight or compromised extensor mechanism. In these cases a lateral release or the snip of quadriceps tendon as described by Insall ${ }^{50}$ may be necessary to facilitate exposure. Patients with longstanding flexion contracture or extensile scars could require more aggressive exposure as tibial tubercle osteotomy. ${ }^{51}$ Once a sufficient exposure is obtained it is important to perform an extensive synoviectomy with debridement and removal of all prosthetic components and bone cement. The area of excision is sometimes widened slightly in areas where there are draining sinuses. The excision of all necrotic tissue is essential as well as complete excision of all pseudo membranes. As for aseptic revision, modular polyethylene is removed first in order to gain more space and reduce tension in the joint area. Even if could be difficult to remove a well fixed tibial component with the femoral component in place, attention should be paid to femur too. Thin osteotoms or small oscillating saw are ideal to get loose the femoral component before to use extraction tools or impactors. In case of extension stems, 
more elaborate procedures are needed especially in case of porous coated or cemented components, up to femoral transection (Figure 5). Osteotomes or saws are used to loosen the cement under a metalbacked tibial component. The removal is then completed by extractors or using the technique of stacked osteotoms. ${ }^{52}$ Reinsertion of a new prosthesis can then be performed as a direct exchange, the so called one stage reimplantation, or after a variable time delay, the two stage procedure.

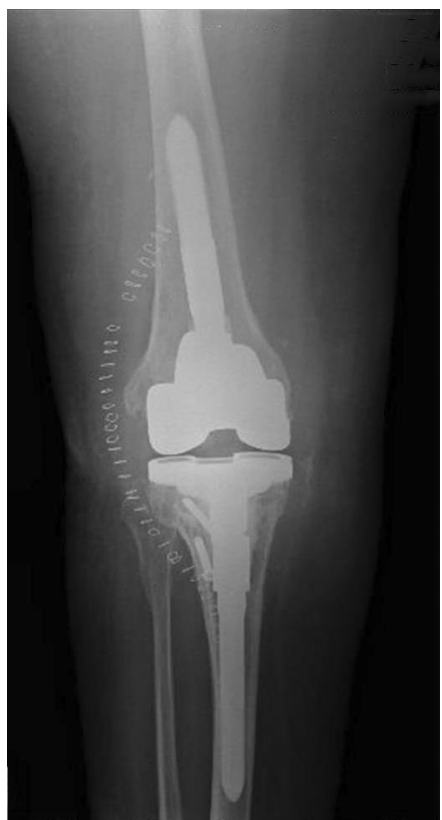

Figure 4 Choice of the incision more laterally.

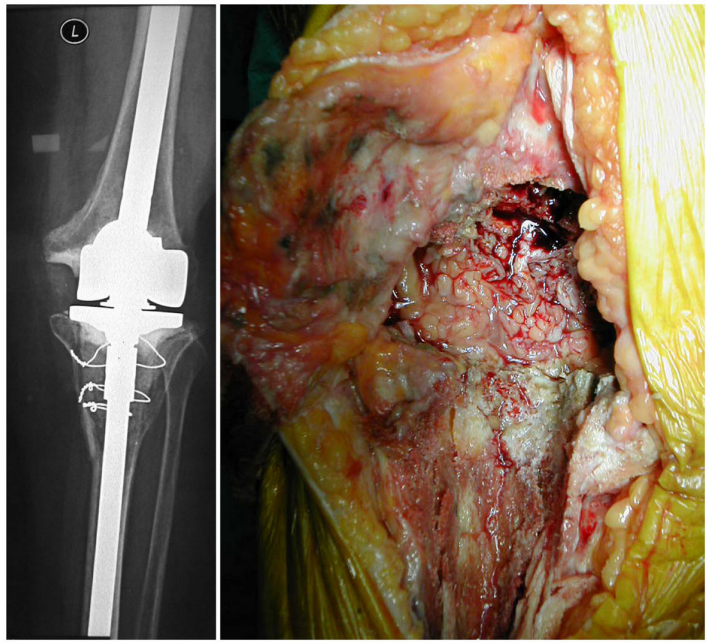

Figure 5 Knee prosthesis infection that need extensive tibial approach to explant long stem.

\section{One-stage prosthetic revision}

One-stage revision of a total knee arthroplasty consists on the removal of the implants and the positioning of a new prosthesis during the same surgical session. This technique has been widely applied from Endo-klinik school of Hamburg since the seventies, who describe in detail the timing for the hip prosthesis replacement. ${ }^{53}$ The fundamental steps of this replacement are represented by: preoperative needle-aspirate to identify germ and choose antibiotics with an experienced microbiologist advice; careful surgical removal of scar tissue, fistulas, necrotic tissue and all the cement's fragments; finally cementation of the prosthesis with antibiotic-loaded bone cement chosen according to the antibiogram. In a recent literature review by Silva et al ${ }^{54}$ were assessed 8 series with a total of 37 cases: the healing of infection was obtained in 34 of these patients (89.2\%) (Table 6). Freeman has shown the largest series with the longest follow-up in 2 subsequent publications in 1985 and 1992:55,56 18 patients have been reported 2 failures related to a case of re-infection with the same germ and a case of new infection, both in patients suffering from rheumatoid arthritis. All cases of infection described by Freeman were caused by gram positive, were not present signs of systemic toxicity and were used cement added with gentamicin and the post-operative antibiotic treatment was prolonged for 3 months. Similar results were reported more recently by Buechel ${ }^{57}$ in 22 revisions were developed only two infections in one case by the same germs while in the other by different germs. Factors associated with the success of one-stage revision surgery seem to be (Table 7): gram-positive infection, absence of fistulas, use of the antibiotic-loaded bone cement, postoperative antibiotic therapy of at least 12 weeks.

Table 6 One-stage prosthetic revision

\begin{tabular}{|c|c|c|c|}
\hline Author & $\mathbf{N}^{\circ}$ of cases & $\begin{array}{l}\text { Success } \\
\text { cases (rate) }\end{array}$ & FU (months) \\
\hline $\begin{array}{l}\text { Freeman MA } \\
\text { JBJS Br } 1985\end{array}$ & 8 & 8 & $12-40$ \\
\hline $\begin{array}{l}\text { Johnson DP } \\
\text { JBJS I } 986\end{array}$ & 2 & 0 & 33.6 \\
\hline $\begin{array}{l}\text { Borden LS } \\
\text { J Arthroplasty } 1987\end{array}$ & 3 & 3 & 51 \\
\hline $\begin{array}{l}\text { Teeny SM } \\
\text { J Arthroplasty } 1990\end{array}$ & 1 & I & 42.5 \\
\hline $\begin{array}{l}\text { Goksan SB } \\
\text { JBJS } 1992\end{array}$ & 18 & 16 & 60 \\
\hline $\begin{array}{l}\text { Hanssen AD } \\
\text { Clin Orthop } 1995\end{array}$ & 2 & 0 & ? \\
\hline $\begin{array}{l}\text { Selmon GP } \\
\text { J Arthroplasty } 1998\end{array}$ & I & I & $?$ \\
\hline $\begin{array}{l}\text { Buechel FF } \\
\text { J Arthroplasty } 2004\end{array}$ & 22 & 20 & 122.4 \\
\hline
\end{tabular}

Literature review

Table 7 Indications for one-stage prosthetic revision

Indications for one-stage prosthetic revision

- GRAM + substained infections

- Absence of sinus tracks

- Use of antibiotic-loaded bone cement according to the antibiogram

- A course of parenteral antibiotics administered post-operatively for 12 weeks

\section{Two-stage prosthetic revision}

Two-stage revision arthroplasty is considered to be the most successful method of treating chronic infected total knee arthroplasties ${ }^{58-60}$ with reported success rates ranged from $37.1 \%$ to $100 \% .{ }^{60,61-65}$ Hovelius e Josefsson in 1979 reported the first successful case of two-stage treatment of infected knee using a chain with 
gentamycin-loaded cement balls inserted into the cavity left by removal of the prosthesis. ${ }^{66}$ However John Insall has been accredited to be the one who standardized the technique ${ }^{61}$ which consists on: a) removal of the prosthesis and all cement from tibia and femur; b) debridement of soft tissues and bone; c) 6 weeks of parenteral antibiotic therapy maintaining a minimum serum bactericidal titer of $1: 8$; implantation of new total knee prosthesis. This three phase protocol has been shown to be an effective method of treatment for infected knee arthroplasty with reasonable expectation of a successful result on condition that all the phases are rigorously followed. The polyethylene tibial insert is removed along with tibial and femoral component, following the steps described before. The wound is thoroughly irrigated with abundant saline solution, and a spacer is formed with antibiotic- impregnated methyl methacrylate.

The treatment goals with the use of Antibiotic Impregnated Cement Spacer (AICS) is two-fold: one mechanical and the other biological. The AICS is useful to stabilize or tension the joint space. Potentially facilitate or make the reimplantation second stage easer. The second biological advantage of AICS is based on the possibility to deliver locally a high dose of antibiotic into the joint between the first and second procedure. The use of these spacers blocks was firstly reported in 1988 by Cohen et al. ${ }^{58}$ who treated three cases with this technique. The infection was controlled in all patients and the Authors were able to succefully implant a well functioning prosthesis. The AICS for total knee surgery are either static (spacer block) or mobile (Figure 6).

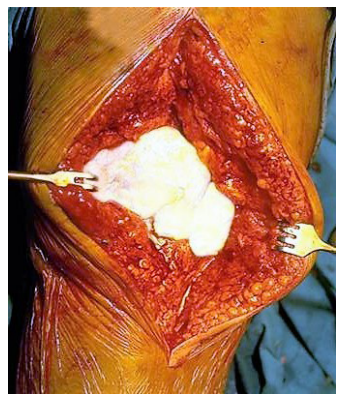

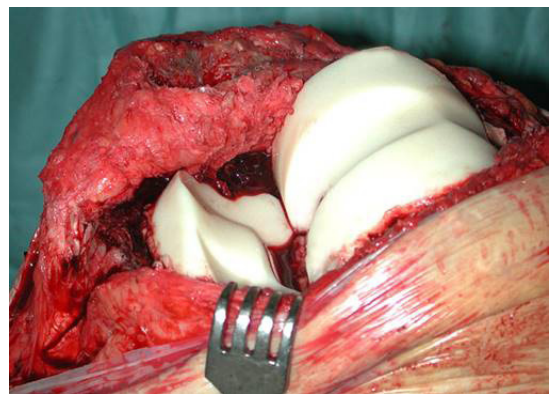

b
Figure 6 Static (a) and mobile (b) AICS.

The last one may be commercially preformed with a fixed antibiotic dose or $^{67}$ or prepared in the operating room through the use of special molds selecting the antibiotic of choice. ${ }^{68}$ According the use of antibiotic to mix into the cement there are large volume of documentation available in literature starting from the work of Buchholz ${ }^{69}$ and Cerretani ${ }^{70}$ particularly studied the association of a mixture of vancomycin $(2 \mathrm{~g})$ and meropemen $(2 \mathrm{~g})$ handled together with $40 \mathrm{~g}$ of plain cement, as a result of increased presence of gentamycin resistant bacteria. From a general point of view the antibiotic should be: a) thermostable, as the polymerization of cement is an exothermic reaction that generates a substantial amount of heat; b) water-soluble, to permit diffusion into surrounding tissues while allowing a gradual release over time for a sustained bactericidal effect c) should have non systemic toxic effects d) should be available in powder. ${ }^{5}$ According to this last argument recently it has been reported by Seldes et al a paper where it was documented the possibility to use liquid gentamycin with the advantage of reduced cost. ${ }^{71}$ The spacer blocks are hand-made in the operating room and are sized to fit the defect created by removal of the infected prosthesis. The choice of antibiotics to add to the cement is based on recommendations of the infectious disease Consultant. Ideally part of the block should be fashioned as a peg in order to anchor it to the tibia and prevent its migration; moreover it is important to mould the spacer in anterior part of the femur so that avoid scarring between femur and extensor mechanism. With spacer block the knee is held in brace or cast and the weight bearing should no allowed because the risk of bone erosion and dislocation. Despite the assumption that spacer block could facilitate the second stage, revision procedure are still difficult and scarring tissue around the knee is nevertheless substantial. As the majority of the morbidity of this technique is related to the scarring and lack of motion between stages, new spacer have been developed in order to allow not only a distraction of the joint but also motion and weight bearing.

Attempts to overcome these problems led to the development of articulating spacer blocks such as the PROSTALAC system, which was first reported in middle nineties. ${ }^{72,73}$ The PROSTALAC spacer is an articulating prosthesis composed primarily of Palacos cement loaded, by the surgeon, with a combination of tobramycin and vancomycin per package. The femoral and tibial components are molded intraoperative into various sizes and thicknesses. The implant has a small metal-on-polyethylene articular surface. In 1995 Hofmann et al described a technique using the original knee component, after sterilization of the femur one, with a new tibial insert and patella. These were cemented in place with highly cured Palacos cement containing $3.6 \mathrm{~g}$ of tobramycin and $2 \mathrm{~g}$ of vancomycin per $40 \mathrm{~g}$ package cement. The articulating surface was polyethylene-on-metal, an optimal configuration for knee motion. More recently a pre-formed articulating spacer made of gentamicin-impregnated acrylic cement has been reported. ${ }^{74}$

Based on a review of the literature, the addition of a small amount of metal and plastic to antibiotic bone cement have not seem to have an adverse effect on infection cure rate and has the advantage of improved function between stages. ${ }^{68,73,75,77}$ Despite its widespread acceptance, two-stage revision has several controversial aspects, including the timing of the procedure with correct evaluation for the reimplantation time and the use of antibiotic-loaded cement at the second stage (Table 8). Most protocols for delayed reimplantation include several weeks of intravenous antibiotic therapy. There has been some debate over the optimal duration for the period of IV antibiotic administration. The antibiotic chosen should be the most effective against the isolated organism and the least toxic for the host. It is important that close monitoring be performed to maintain serum levels in therapeutic range. ${ }^{60}$

Table 8 Negative prognostic factors during two-stage revision surgery

- Infection from high-virulence microorganism or polimicrobic infection

- Immunocompromised patients or patients with bad general conditions

- Early revision (<6 weeks)

- Prosthetic component cementation without antibiotic

- Bad skin local condition

The majority of reports using 6 weeks have shown this to be effective. A controversial issue in field of two stage revision is related with correct choice to perform the second stage been sure that the infection is cured. Insall et a $l^{61}$ recommended that antibiotic therapy be stopped and then aspiration be performed before revision artrhroplasty. Others ${ }^{54}$ advocate cultures of the knee aspirate 4 weeks after stopping the antibiotics and before second stage re-implantation. We believe that this is unnecessary as a routine and should be restricted to those patients with a suspicion of persistent infection and 
in the presence of elevated inflammatory markers. The monitoring of serological test (CRP, ESR and fibrinogen) could be useful to detect that the knee is free of infection and its possible to perform a final procedure. In our experience the combination of at least two of three tests with values higher than the cut-offs is reliable for predicting the infection. ${ }^{78}$ Scintigraphy, needle-aspirate cell count and culture can integrate the pre-operative evaluation in Doubtful cases. Once infection control is established the second stage re-implantation is performed and multiple tissue samples should be taken at the second stage procedure. Even if the use of uncemented prosthesis at the second stage has been questioned at the light of recent promising result, ${ }^{79}$ the use of antibiotic-loaded cement at revision has been shown to reduce the rates of re-infection (Table 9). Hanssen and Rand ${ }^{80}$ had a success rate of $82 \%$ without antibiotic cement at the second stage procedure, compared with $90 \%$ when an antibiotic was used. Nowadays most surgeons prefer to use cement at the metaphyseal area with cementless stems.

Table 9 Two-stage septic revision surgery

\begin{tabular}{|c|c|c|c|}
\hline Author & $\mathbf{N}^{\circ}$ of cases & $\begin{array}{l}\text { Success cases } \\
\text { (rate) }\end{array}$ & FU (months) \\
\hline $\begin{array}{l}\text { Insall JN } \\
\text { JBJS I } 983\end{array}$ & $* 11$ & $8(72,7 \%)$ & 36 \\
\hline $\begin{array}{l}\text { Borden LS } \\
\text { J Arthroplasty } 1987\end{array}$ & $* 11$ & $10(90,9)$ & 51 \\
\hline $\begin{array}{l}\text { Teeny SM } \\
\text { J Arthroplasty } 1990\end{array}$ & $* 10$ & $10(100 \%)$ & 42.5 \\
\hline $\begin{array}{l}\text { Windsor RE } \\
\text { JBJS 1990* }\end{array}$ & $* 38$ & $34(89,4 \%)$ & 48 \\
\hline $\begin{array}{l}\text { Wilson MG } \\
\text { JBJS } 1990\end{array}$ & $* 20$ & 16(80\%) & 34 \\
\hline $\begin{array}{l}\text { Kramhoft M } \\
\text { J Arthroplasty } 1994\end{array}$ & $* 15$ & II $(73,3)$ & n.r. \\
\hline $\begin{array}{l}\text { Wasielewsky RC } \\
\text { J Arthroplasty } 1996\end{array}$ & $\begin{array}{l}* 6 \text { prec } \\
* 44 \text { tard }\end{array}$ & $\begin{array}{l}6(100 \%) \\
40(90,9 \%)\end{array}$ & 57 \\
\hline $\begin{array}{l}\text { Mc Pherson } \\
\text { Clin Orthop 1997* }\end{array}$ & $* 21$ & $20(95,2 \%)$ & \\
\hline $\begin{array}{l}\text { Hirakawa K } \\
\text { J Arthroplasty } 1998\end{array}$ & 55 & $4 \mathrm{I}(74,5 \%)$ & 61 \\
\hline $\begin{array}{l}\text { Segawa H } \\
\text { JBJS } 1999\end{array}$ & 29 & $24(83 \%)$ & 48 \\
\hline $\begin{array}{l}\text { Fehring TK } \\
\text { Clin Orthop } 2000\end{array}$ & $\begin{array}{l}* \quad 25 \\
* * 15\end{array}$ & $\begin{array}{l}22(88 \%) \\
15(100 \%)\end{array}$ & $\begin{array}{l}36 \\
27\end{array}$ \\
\hline Emerson $\mathrm{RH}$ & * 26 & 18 (69.3\%) & 90 \\
\hline Clin Orthop 2002 & $* * 22$ & $20(90.9 \%)$ & 45 \\
\hline $\begin{array}{l}\text { Meek RMD } \\
\text { JBJS } 2003\end{array}$ & $* * 47$ & $45(96 \%)$ & 47 \\
\hline $\begin{array}{l}\text { Hallem AA } \\
\text { Clin Orthop } 2004\end{array}$ & 96 & 87 (91\%) & 90 \\
\hline $\begin{array}{l}\text { Durbhakula } \\
\text { J Arthrop 2004** }\end{array}$ & $* * 24$ & $22(92 \%)$ & 33 \\
\hline $\begin{array}{l}\text { Hoad-Reddick DA } \\
\text { JBJS (Br) }\end{array}$ & $* * 38$ & $34(89 \%)$ & 56 \\
\hline $\begin{array}{l}\text { Hofmann A } \\
\text { Clin Orthop } 2005\end{array}$ & $* * 50$ & $46(92 \%)$ & 73 \\
\hline
\end{tabular}

Literature review (*, spacer block; **, articulating spacer).

\section{Arthrodesis}

Arthrodesis is a salvage procedure for an infection of total knee arthroplasty, that aims to achieve stable and painless joint despite a complete loss of motion. ${ }^{6,81,82}$ In case of knee arthroplasty septic failure the indications for arthrodesis can be summarized as: highly resistant infection to antibiotic therapy, extensor deficits, poor skin coverage that can not be adequately reconstructed, younger age, and immunodeficiency. ${ }^{6,11,17,60,83}$ Relative contraindications to arthrodesis are ipsilateral hip or ankle pathologies, extensive bone loss, and contralateral amputation. ${ }^{6,11,60}$ Different surgery procedures have been proposed to obtain knee arthrodesis, but at this time external fixation ${ }^{81,84,87}$ (Table 10) and the intramedullary synthesis ${ }^{6,85,86}$ (Table 11) are the most frequently used techniques.

Table I0 Femoral-tibial arthrodesis by external fixator

\begin{tabular}{lll}
\hline Author & $\mathbf{N}^{\circ}$ of cases & Fusion rate \\
\hline $\begin{array}{l}\text { KnutsonK } \\
\text { JBJS I984 }\end{array}$ & 7 I & $33(46 \%)$ \\
$\begin{array}{l}\text { Green SA } \\
\text { Orthop / } 985\end{array}$ & 7 & $3(43 \%)$ \\
$\begin{array}{l}\text { Hagemann } \\
\text { JBJS I986 }\end{array}$ & 14 & $9(64 \%)$ \\
$\begin{array}{l}\text { Rand J } \\
\text { JBJS I987 }\end{array}$ & 28 & $20(71 \%)$ \\
$\begin{array}{l}\text { Hak DJ } \\
\text { IClin Orthop /995 }\end{array}$ & 22 & $12(55 \%)$ \\
\hline
\end{tabular}

Literature review

Table I I Femoral-tibial arthrodesis by intramedullary nail

\begin{tabular}{|c|c|c|}
\hline Author & $\mathbf{N}^{\circ}$ of cases & Fusion rate \\
\hline $\begin{array}{l}\text { KnutsonK } \\
\text { Clin Othop } 1984\end{array}$ & 10 & $9(90 \%)$ \\
\hline $\begin{array}{l}\text { Harris C } \\
\text { Clin Orthop } 1985\end{array}$ & 8 & $7(88 \%)$ \\
\hline $\begin{array}{l}\text { EllingsenDE } \\
\text { JBJS } 1986\end{array}$ & 18 & $16(89 \%)$ \\
\hline $\begin{array}{l}\text { Puranen J } \\
\text { JBJS } 1990\end{array}$ & 15 & $12(80 \%)$ \\
\hline $\begin{array}{l}\text { DonleyBG } \\
\text { JBJS I99I }\end{array}$ & 9 & $8(89 \%)$ \\
\hline $\begin{array}{l}\text { FerroneJD } \\
\text { Comp. Orthop } 1996\end{array}$ & 8 & $8(100 \%)$ \\
\hline $\begin{array}{l}\text { Waldman BJ } \\
\text { Clin Orthop } 1999\end{array}$ & 21 & $20(95 \%)$ \\
\hline $\begin{array}{l}\text { Incavo SJ } \\
\text { J Arthrop } 2000\end{array}$ & 17 & $17(100 \%)$ \\
\hline
\end{tabular}

Literature review

The problems associated to this type of arthrodesis, regardless of the surgical choice, are related to the entity of bone loss, bone shortening, alteration of deambulation and finally the possible persistence of knee infection. ${ }^{6,85,86}$ The percentage of success with external fixation varies widely according to the characteristics of the device used (Figure 7). In the early 80 's, the success rate observed 
with monoplanar external fixator was poor with union in only $1 / 3$ of cases. ${ }^{85,86,88}$ Enhancement of fixator stability increased the union rate reaching values of $68 \%$ with biplanar systems ${ }^{86}$ On the contrary Hak et al. showed only a small difference in union percentage by changing from monoaxial to biplanar fixator.
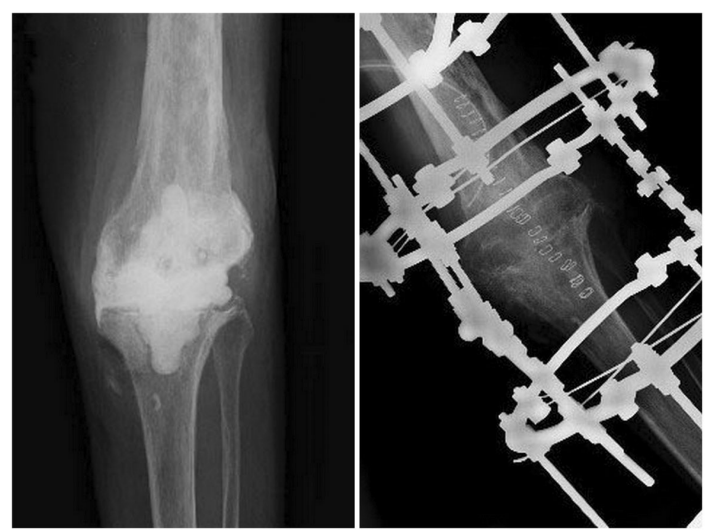

Figure 7 Arthrodesis by llizarov method.

These data suggest that the bone union depends both on the fixator stability and by other factors, such as the type of prosthesis previously used which may influence the extent of bone loss and the bone quality, and consequently the bone contact and the possibility of compression. The best results have been observed after failure of resurfacing prosthesis compared with hinge implants, especially with intramedullary stems ${ }^{87}$ because the bone contact and compression of the articular heads are limited in the presence of cortical or sclerotic bone.

The arthrodesis by intramedullary nail (Figure 8) has gained increasing favour, due to rates of fusion greater than $80 \%$ of cases ${ }^{86,89,90}$ despite the literature is often based on heterogeneous series of cases secondary to septic or aseptic loosening and bone resection for malignancy. ${ }^{6,91,92}$

Waldman et al. ${ }^{41}$ showed the results of a multicenter study on 21 patients treated by modular titanium nail for septic knee arthroplasty loosening followed for 2,4 years ( 2 to 7.5 years): a solid union was obtained in 20 of 21 patients about 6,3 months after surgery. The authors underline the advantages of this method in contrast to the traditional technique that included the introduction of a long nail from the trochanteric region. The modularity and the morphology of the nails allow it to adapt to different dimensions of the femoral and tibial canal and to facilitate the alignment of the limb. In the presence of bone loss is possible the use of Titanium spacers or bone grafts. Although no patients in this series developed a new infection, the possibility that this event will occur is high, due to the presence of nail. For this reason a two stages protocol is recommended: the initial removal of the prosthesis is followed by nail arthrodesis. ${ }^{82-90}$

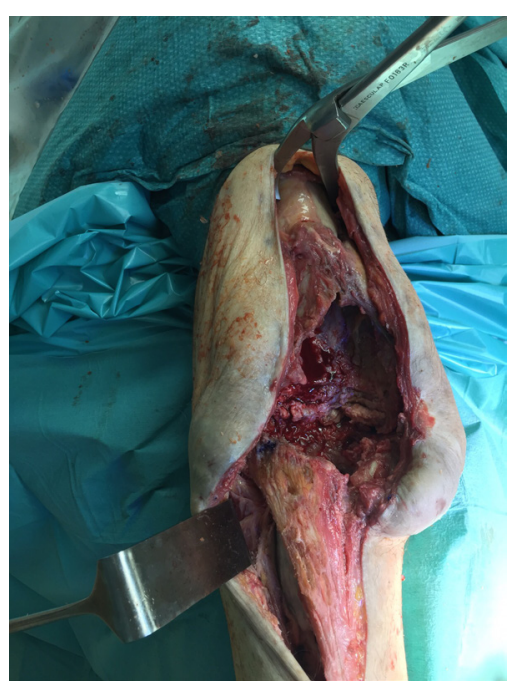

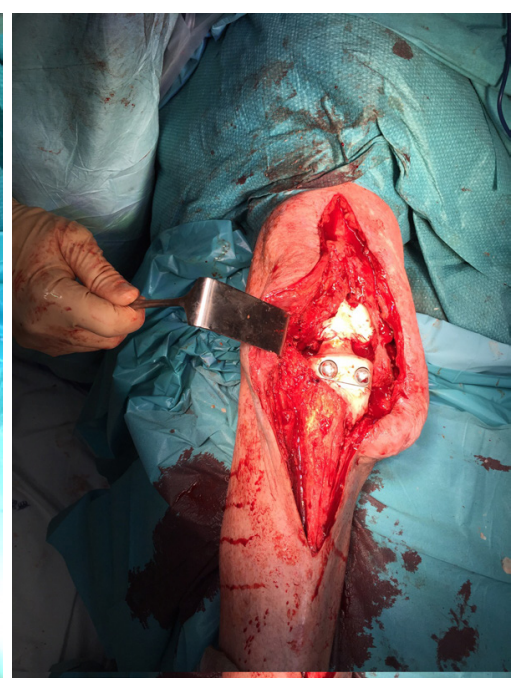

b

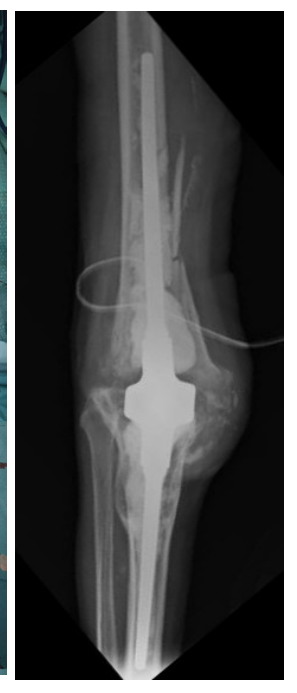

c

Figure 8 Arthrodesis by intramedullary nail: a) intraoperative images b-c) post-operative x-Ray.

\section{Resection arthroplasty}

The implant removal without the intention to further positioning of a new prosthesis was restricted to situations of serious infections in debilitated patients. Although the procedure was considered effective for infection healing, the consequent knee pain and instability, and the difficulty in walking makes it difficult to use. Now-days it should be considered only as exceptional treatment.

\section{Amputation}

Above knee amputation or rarely hip disarticulation is a salvage procedure for the failed infected total knee arthroplasty. The indication for amputation is life threatening sepsis particularly if associate with massive bone loss. Amputation with prosthetic fitting will allow the most rapid rehabilitation and avoid the morbidity of additional surgical procedure. However it should take into account that many of elderly patients may became limited ambulators or no ambulatory for psychological or objective difficulty.

\section{Conclusion}

i. A painful knee arthroplasty should be considered potentially infected.

ii. The diagnosis of infection is based on a careful analysis of patient history, imaging and laboratory records, with the use of the new molecular biology strategies.

iii. Pre- and intra-operative cultures are essential to begin a targeted antibiotic treatment. The isolation of the germ can be generally obtained through fine-needle aspiration, which should be 
repeated in doubtful cases. The patient should have stopped antibiotics therapy for at least 3 weeks. Local anaesthetics and saline solutions have bactericidal and so should be avoided.

iv. The isolation of the germ sometimes requires an open biopsy. In these cases it is useful to perform multiple specimens.

v. In acute Staphylococcus epidermidis or Streptococcus infections, the debridement with replacement of polyethylene leads to healing if the treatment is performed within $2 / 3$ weeks. In these situations, an empiric antibiotic therapy and the delay in the use of a targeted antibiotic inevitably lead to chronic infection.

vi. One-stage revision is indicated in gram-positive infection if there are no cutaneous fistulas or a state of immunodeficiency. The prosthesis must be fixed by antibiotic-loaded bone cement and the systemic antibiotic therapy should be continued for at least 12 weeks.

vii. Two-stage revision is the gold standard in chronic infections. There are still argument relating to the choice of antibiotic to be loaded in spacer and if this should be static or articulated. Despite the high success rate of this procedure, a number of re-infections occur in almost all series; also currently there are no reliable criteria to diagnose septic process persistence. The compromised condition of the patient, both general and local, as well as the presence of a polymicrobial flora or high strength germs is poor prognostic factor. There are evidences that the antibiotic-loaded bone cement reduces the incidence of infection recurrence while there are no indications to the antibiotics use after implant revision.

viii. Knee arthrodesis is a salvage procedure in antibiotic-resistant infections, extensor deficits, poor skin coverage that can not be adequately reconstructed, younger age, and compromised immune status.

ix. The antibiotic-suppressive therapy prevents the growth and development of bacteria, allowing control of the disease, but does not allow the cure of the infection. It is indicated in the presence of a stable prosthesis, germ with low virulence, sensitive to antibacterial drugs administered orally, and when there is a contraindication to surgery.

x. Resection arthroplasty is poorly indicated in knee surgery.

\section{References}

1. Wang CJ, Huang TW, Wang JW, et al. The often poor clinical outcome of infected total knee arthroplasty. J Arthroplasty. 2002;17(5):608-614.

2. Gristina AG, Costerton JW. Bacterial adherence to biomaterials and tissue. The significance of its role in clinical sepsis. J Bone Joint Surg Am. 1985;67(2):264-273.

3. Ghibellini F, Ceffa R. Manuale- Atlante di trattamento delle infezioni di protesi articolari e di utilizzo delle miscele di cemento con antibiotici. Roma, Mediprint 1997.

4. Esteban J, Sorlí L, Alentorn-Geli E, et al. Conventional and molecular diagnostic strategies for prosthetic joint infections. Expert Rev Mol Diagn. 2014;14(1):83-96.

5. Van de Belt H, Neut D, Schenk W, et al. Infection of orthopedic implants and the use of antibiotic-loaded bone cements. Acta Orthop Scand. 2001;72(6):557-571.
6. Mulvey TJ, Thornhill TS. Infected total knee arthroplasty. In: Surgery of the knee. Insall JN, Scott WN. 3th Edition. New York, Churchill Livingston 2001.

7. Gerwin M, Rothaus KO, Windsor RE, et al. Gastrocnemius muscle flap coverage of exposed or infected knee prostheses. Clin Orthop Relat Res. 1993;(286):64-70.

8. Casanova D, Hulard, O, Zalta R, et al. Management of wounds of exposed or infected knee prostheses. Scand J Plast Reconstr Surg Hand Surg. 2001;35(1):71-77.

9. Jones EC, Insall JN, Inglis AE, et al. GUEPAR knee arthroplasty and late complication. Clin Ortop Relat Res. 1979;140:145-152.

10. Rorabeck CH. Session IV: Salvage of the infected total knee replacement. Infection: the problem. Clin Orthop Relat Res. 2002;404:113-115.

11. Johnson DP, Bannister GC. The outcome of infected arthroplasty of the knee. J Bone Joint Surg Br. 1986;68(2):289-291.

12. Hanssen AD, Osmon DR, Nelson CL. Prevention of deep periprosthetic joint infection. An Instructional Course Lecture, The American Academy of Orthopaedics Surgeons. J Bone Joint Surg. 1996;78(A)3:458-471.

13. Berbari EF, Hanssen AD, Duffy MC, et al. Risk factors for prosthetic joint infection: case-control study. Clin Infect Dis. 1998;27(5):12471254.

14. Poss R, Thornhill TS, Ewald FC, et al. Factors influencing the incidence and outcome of infection following total joint arthroplasty. Clin Orthop Relat Res. 1984;182:117-126.

15. Peersman G, Laskin R, Davis J, et al. Infection in total knee replacement: a retrospective review of 6489 total knee replacements. Clin Orthop Relat Res. 2001;392:15-323.

16. Chiu FY, Lin CF, Chen CM, et al. Cefuroxime-impregnated cement at primary total knee arthroplasty in diabetes mellitus. A prospective, randomised study. J Bone Joint Surg Br. 2001;83(5):691-695.

17. Stern SH, Insall JN, Windsor RE, et al. Total knee arthroplasty in patients with psoriasis. Clin Orthop Relat Res. 1989;248:108-110.

18. Rand JA. Sepsis following total knee arthroplasty. In: Total knee arthroplasty. Rand JA. Ed. New York Raven Press Ltd. 1993

19. Windsor RE, Insall JN, Urs WK, et al. Two-stage reimplantation for the salvage of total knee arthroplasty complicated by infection. Further follow-up and refinement of indications. J Bone Joint Surg Am. 1990;72(2):272-278.

20. Sudanese A, Toni A, Busanelli L, et al. Diagnostic protocol in prosthetic loosening. Chir Organi Mov. 1994;79(4):257-267.

21. Duff GP, Lachiewicz PF, Kelley SS. Aspiration of the knee joint before revision arthroplasty. Clin Orthop Relat Res. 1996;331:132-139.

22. Atkins BL, Athanasou N, Deeks JJ, et al. Prospective evaluation of criteria for microbiological diagnosis of prosthetic-joint infection at revision arthroplasty. The OSIRIS Collaborative Study Group. J Clin Microbiol. 1998;36(10):2932-2939.

23. Puig-Verdié L, Alentorn-Geli E, González-Cuevas A, et al. Implant sonication increases the diagnostic accuracy of infection in patients with delayed, but not early, orthopaedic implant failure. Bone Joint J. 2013;95-B(2):244-249.

24. Frangiamore SJ, Gajewski ND, Saleh A, et al. $\alpha$-Defensin Accuracy to Diagnose Periprosthetic Joint Infection-Best Available Test? J Arthroplasty. 2016;31(2):456-460.

25. Deirmengian C, Kardos K, Kilmartin P, et al. The alpha-defensin test for periprosthetic joint infection outperforms the leukocyte esterase test strip. Clin Orthop Relat Res. 2015;473(1):198-203. 
26. Deirmengian C, Kardos K, Kilmartin P, et al. The Alpha-defensin Test for Periprosthetic Joint Infection Responds to a Wide Spectrum of Organisms. Clin Orthop Relat Res. 2015;473(7):2229-2235.

27. Trampuz A, Piper KE, Jacobson MJ, et al. Sonication of explanted prosthetic components in bags for diagnosis of prosthetic joint infection is associated with risk of contamination. NEngl J Med. 2007;357(7):654663.

28. M Portillo ME, Salvadó M, Trampuz A, et al. Sonication versus vortexing of implants for diagnosis of prosthetic joint infection. J Clin Microbiol. 2013;51(2):591-594.

29. Esteban J, Alvarez-Alvarez B, Blanco A, et al. Prolonged incubation time does not increase sensitivity for the diagnosis of implant-related infection using samples prepared by sonication of the implants. Bone Joint J. 2013;95-B(7):1001-1006.

30. Cazanave C, Greenwood-Quaintance KE, Hanssen AD, et al. Rapid molecular microbiologic diagnosis of prosthetic joint infection. J Clin Microbiol. 2013;51(7):2280-2287.

31. Achermann Y, Vogt M, Leunig M, et al. Improved diagnosis of periprosthetic joint infection by multiplex PCR of sonication fluid from removed implants. J Clin Microbiol. 2010;48(4):1208-1214.

32. Bergin PF, Doppelt JD, Hamilton WG, et al. Detection of periprosthetic infections with use of ribosomal RNA-based polymerase chain reaction. J Bone Joint Surg Am. 2010;92(3):654-63.

33. Rand JA. Alternatives to reimplantation for salvage of the tota knee arthroplasty complicated by infection. Instr Course Lect. 1993;75(2):282-289.

34. Tsukayama DT, Goldberg VM, Kyle R. Diagnosis and management of infection after total knee arthroplasty. J Bone Joint Surg Am. 2003;85(Suppl 1):75-80.

35. Isiklar ZU, Darouiche RO, Landon GC, et al. Efficacy of antibiotics alone for orthopaedic device related infections. Clin Orthop Relat Res. 1996;332:184-189.

36. Schoifet SD, Morrey BF. Treatment of infection after total knee arthroplasty by débridement with retention of the components. $J$ Bone Joint Surg Am. 1990;72(9):1383-1390.

37. Teeny SM, Dorr L, Murata G, et al. Treatment of infected total knee arthroplasty. Irrigation and debridement versus two-stage reimplantation. J Arthroplasty. 1990;5(1):35-39.

38. Wasielewski RC, Barden RM, Rosenberg AG. Results of different surgical procedures on total knee arthroplasty infections. J Arthroplasty. 1996;11(8):931-938.

39. Deirmengian C, Greenbaum J, Lotke PA, et al. Limited success with open debridement and retention of components in the treatment of acute Staphylococcus aureus infections after total knee arthroplasty. $J$ Arthroplasty. 2003;18(7 Suppl 1):22-26.

40. Ilahi OA, Al-Habbal GA, Bocell JR, et al. Arthroscopic debridement of acute periprosthetic septic arthritis of the knee. Arthroscopy. 2005;21(3):303-306.

41. Waldman BJ, Hostin E, Mont MA, et al. Infected total knee arthroplasty treated by arthroscopic irrigation and débridement. J Arthroplasty. 2000;15(4):430-436.

42. Tsumura H, Ikeda S, Ono T, et al. Synovectomy, debridement, and continuous irrigation for infected total knee arthroplasty. Int Orthop. 2005;29(2):113-116.

43. Kawashima M, Torisu T, Kamo Y, et al. The treatment of pyogenic bone and joint infections by closed irrigation-suction. Clin Orthop Relat Res. 1980;148:240-244.

44. Cierny G, DiPasquale D. Periprosthetic total joint infections: staging, treatment, and outcomes. Clin Orthop Relat Res. 2002;403:23-28.
45. England SP, Stern SH, Insall JN, et al. Total knee arthroplasty in diabetes mellitus. Clin Orthop Relat Res. 1990;260:130-134.

46. Garner RW, Mowat AG, Hazleman BL. Wound healing after operations of patients with rheumatoid arthritis. J Bone Joint Surg Br. 1973;55(1):134 44.

47. Thornhill TS, Dalziel RW, Sledge CB. Alternatives to arthrodesis for the failed total knee arthroplasty. Clin Orthop Relat Res. 1982;170:131-140.

48. Marín LA, Salido JA, López A, et al. Preoperative nutritional evaluation as a prognostic tool for wound healing. Acta Orthop Scand. 2002;73(1):2-5.

49. Greene KA, Wilde AH, Stulberg BN. Preoperative nutritional status of total joint patients. Relationship to postoperative wound complications. $J$ Arthroplasty. 1991;6(4):321-325.

50. Garvin KL, Scuderi G, Insall JN. Evolution of the quadriceps snip. Clin Orthop Relat Res. 1995;321:131-137.

51. Clarke HD. Tibial tubercle osteotomy. J Knee Surg. 2003;16(1):58-61.

52. Moreland J. Technique for removal of prosthesis and cement in knee revision surgery. In: Revision total knee arthroplasty. Engh GA, Rorabeck CH. Batimore, Williamms \& wilkins 1997.

53. Buchholz HW, Elson RA, Engelbrecht E, et al. Management of deep infection of total hip replacement. J Bone Joint Surg Br. 1981;63(3):342353.

54. Silva M, Tharani R, Schmalzried TP. Results of direct exchange or debridement of the infected total knee arthroplasty. Clin Orthop Relat Res. 2002;404:125-131.

55. Freeman MA, Sudlow RA, Casewell MW, et al. The management of infected total knee replacements. J Bone Joint Surg Br. 1985;67(5):764768.

56. Göksan SB, Freeman MA. One-stage reimplantation for infected total knee arthroplasty. J Bone Joint Surg Br. 1992;74(1):78-82.

57. Buechel FF. The infected total knee arthroplasty: just when you thought it was over. J Arthroplasty. 2004;19(4 Suppl 1):51-55.

58. Cohen JC, Hozack WJ, Cuckler JM, et al. Two-stage reimplantation of septic total knee arthroplasty. Report of three cases using an antibioticPMMA spacer block. J Arthroplasty. 1988;3(4):369-377.

59. Kurd MF, Ghanem E, Steinbrecher J, et al. Two-stage exchange knee arthroplasty: does resistance of the infecting organism influence the outcome? Clin Orthop Relat Res. 2010;468(8):2060-2066.

60. Insall JN, Thompson FM, Brause BD. Two-stage reimplantation for the salvage of infected total knee arthroplasty. J Bone Joint Surg Am. 1983;65(8):1087-1098.

61. Goldman RT, Scuderi GR, Insall JN. 2-stage reimplantation for infected total knee replacement. Clin Orthop Relat Res. 1996;331:118-124.

62. Haleem AA, Berry DJ, Hanssen AD. Mid-term to long-term followup of two-stage reimplantation for infected total knee arthroplasty. Clin Orthop Relat Res. 2004;428:35-39.

63. McLaren AC, Spooner CE. Salvage of infected total knee components. Clin Orthop Relat Res. 1996;331:146-150.

64. Mittal Y, Fehring TK, Hanssen A, et al. Two-stage reimplantation for periprosthetic knee infection involving resistant organisms. J Bone Joint Surg Am. 2007;89(6):1227-1231.

65. Hirakawa K, Stulberg BN, Wilde AH, et al. Results of 2-stage reimplantation for infected total knee arthroplasty. $J$ Arthroplasty. 1998;13(1):22-28.

66. Hovelius L, Josefsson G. An alternative method for exchange operation of infected arthroplasty. Acta Orthop Scand. 1979;50(1):93-96. 
67. Pitto RP, Spika IA. Antibiotic-loaded bone cement spacers in twostage management of infected total knee arthroplasty. Int Orthop. 2004;28(3):129-133.

68. Duncan CP, Beauchamp C, Masri BA. The antibiotic loaded joint replacement system: a novel approach to the management of the infected knee replacement. J Bone Joint Surg Br. 1992;74(Suppl 3):296.

69. Buchholz HW, Elson RA, Heinert K. Antibiotic-loaded acrylic cement: current concepts. Clin Orthop Relat Res. 1984;190:96-108.

70. Cerretani D, Giorgi G, Fornara $\mathrm{P}$, et al. The in vitro elution characteristics of vancomycin combined with imipenem-cilastatin in acrylic bonecements: a pharmacokinetic study. J Arthroplasty. 2002;17(5):619-626.

71. Seldes RM, Winiarsky R, Jordan LC, et al. Liquid gentamicin in bone cement: a laboratory study of a potentially more cost-effective cement spacer. J Bone Joint Surg Am. 2005;87(2):268-272.

72. Masri BA, Kendall RW, Duncan CP, et al. Two-stage exchange arthroplasty using a functional antibiotic-loaded spacer in the treatment of the infected knee replacement: the Vancouver experience. Semin Arthroplasty. 1994;5(3):122-136.

73. Scott IR, Stockley I, Getty CJ. Exchange arthroplasty for infected knee replacements. A new two-stage method. J Bone Joint Surg Br. 1993;75(1):28-31.

74. Castelli CC, Ferrari R, Pitto RP, et al. Pre-formed articulating knee spacer in two-stage revision for the infected total knee arthroplasty. Int Orthop. 2005;29(5):305-308.

75. Emerson RH Jr, Muncie M, Tarbox TR, et al. Comparison of a static with a mobile spacer in total knee infection. Clin Orthop Relat Res. 2002;404:132-138.

76. Meek RM, Masri BA, Dunlop D, et al. Patient satisfaction and functional status after treatment of infection at the site of a total knee arthroplasty with use of the PROSTALAC articulating spacer. J Bone Joint Surg Am. 2003;85(10):1888-1892.

77. Durbhakula SM, Czajka J, Fuchs MD, et al. Antibiotic-loaded articulating cement spacer in the 2 -stage exchange of infected total knee arthroplasty. J Arthroplasty. 2004;19(6):768-774.

78. Savarino L, Tigani D, Baldini N, et al. Pre-operative diagnosis of infection in total knee arthroplasty: an algorithm. Knee Surg Sports Traumatol Arthrosc. 2009;17(6):667-675.
79. Whiteside LA. Cementless fixation in revision total knee arthroplasty. Clin Orthop Relat Res. 1993;286:160-167.

80. Hanssen AD, Rand JA. Evaluation and treatment of infection at the site of a total hip or knee arthroplasty. Instr Course Lect. 1999;48:111-122.

81. Conway JD, Mont MA, Bezwada HP. Arthrodesis of the knee. J Bone Joint Surg Am. 2004;86(4):835-848.

82. Incavo SJ, Lilly JW, Bartlett CS, et al. Arthrodesis of the knee: experience with intramedullary nailing. J Arthroplasty. 2000;15(7):871-876.

83. Mont MA, Waldman BJ, Hungerford DS. Evaluation of preoperative cultures before second-stage reimplantation of a total knee prosthesis complicated by infection. A comparison-group study. J Bone Joint Surg Am. 2000;82(11):1552-1557.

84. Hoad-Reddick DA, Evans CR, Norman P, et al. Is there a role for extended antibiotic therapy in a two-stage revision of the infected knee arthroplasty? J Bone Joint Surg Br. 2005;87(2):171-174.

85. Wiedel JD. Salvage of infected total knee fusion: the last option. Clin Orthop Relat Res. 2002;404:139-142.

86. Rand JA, Bryan RS, Chao EY. Failed total knee arthroplasty treated by arthrodesis of the knee using the Ace-Fischer apparatus. J Bone Joint Surg Am. 1987;69(1):39-45.

87. Hak DJ, Lieberman JR, Finerman GA. Single plane and biplane external fixators for knee arthrodesis. Clin Orthop Relat Res. 1995;316:134-144.

88. Rand JA, Bryan RS. Reimplantation for the salvage of an infected total knee arthroplasty. J Bone Joint Surg Am. 1983;65(8):1081-1086.

89. Wilde AH, Stearns KL. Intramedullary fixation for arthrodesis of the knee after infected total knee arthroplasty. Clin Orthop Relat Res. 1989;248:87-92.

90. Donley BG, Matthews LS, Kaufer H. Arthrodesis of the knee with an intramedullary nail. J Bone Joint Surg Am. 1991;73(6):907-913.

91. Arroyo JS, Garvin KL, Neff JR. Arthrodesis of the knee with a modular titanium intramedullary nail. J Bone Joint Surg Am. 1997;79(1):26-35.

92. McQueen DA, Cooke FW, Hahn DL. Intramedullary compression arthrodesis of the knee: early experience with a new device and technique. J Arthroplasty. 2005;20(1):72-78. 